27. This research was supported by the Medical Foundation "Koningin Elisabeth," the "Belgische Vereniging voor Strijd tegen Mucoviscidose," and the "Nationaal Fonds voor Wetenschappelijk Onderzoek" S2/5-I. D. E. 37.

28. Requests for reprints should be addressed to: Vera Rogiers, V. U. B., Laboratorium Farmacognosie en Toxicologie, Laarbeeklaan, 103, B-1090 Brussel, België.
29. The authors thank Labaz, Belgium for the use of their laboratory equipment. G. De Dobbeleer is also thanked for her efficient technical assistance. Finally, we wish to thank the cystic fibrosis patients and the healthy volunteers for their kind cooperation.

30. Received for publication August 13, 1983

31. Accepted for publication September 30, 1983.

\title{
Metabolic Consequences of Intrauterine Growth Retardation in Very Low Birthweight Infants
}

\author{
PHILLIPPE CHESSEX, ${ }^{45}$ BRIAN REICHMAN,${ }^{46}$ GASTON VERELLEN,${ }^{47}$ GUY PUTET,${ }^{48}$ \\ JOHN M. SMITH, TIBOR HEIM, ${ }^{49}$ and PAUL R. SWYER ${ }^{50}$ \\ Departments of Paediatrics, Nutrition, and Medical Engineering, The University of Toronto, and the Research \\ Institute, The Hospital for Sick Children, Toronto, Ontario, Canada
}

\begin{abstract}
Summary
By the combination of energy and macronutrient balances, continuous open circuit computerized indirect calorimetry, and anthropometry, we have compared small for gestational age (SGA) and appropriate for gestational age (AGA) very low birthweight infants with respect to metabolizable energy intake (mean \pm SE: $125.9 \pm 2.5$ versus $130.4 \pm 3.5 \mathrm{kcal} / \mathrm{kg} \cdot$ day), energy expenditure $(67.4 \pm 1.3$ versus $62.6 \pm 0.9 \mathrm{kcal} / \mathrm{kg} \cdot$ day $)$, storage of energy and macronutrients and growth. Fourteen studies in six SGA infants (gestational age, $33.1 \pm 0.3$ weeks; birthweight, $1120 \pm 30 \mathrm{~g}$ ) and 22 studies in 13 AGA infants (gestational age, $29.3 \pm 0.4$ weeks; birthweight, $1155 \pm 40$ g) were performed. The SGA infants had a lower absorption of fat $(68.7 \pm 3.2$ versus $79.7 \pm 1.7 \%)$ and protein $(69.1 \pm 3.2$ versus $83.4 \pm 1.5 \%)$ and hence increased $(P<0.001)$ energy loss in excreta $(29.9 \pm 2.8$ versus $18.2 \pm 1.5 \mathrm{kcal} / \mathrm{kg} \cdot$ day). The significant hypermetabolism of SGA infants by $4.8 \mathrm{kcal} / \mathrm{kg}$. day was associated with an increased fat oxidation. Despite lower energy storage, SGA infants were gaining weight $(19.4 \pm 0.9 \mathrm{~g} / \mathrm{kg} \cdot$ day $)$, length $(1.25 \pm$ $0.14 \mathrm{~cm} /$ week $)$, and head circumference $(1.16 \pm 0.9 \mathrm{~cm} /$ week $)$ at higher rates than the AGA group. The energy storage per $g$ weight gain was lower $(P<0.001)$ in the SGA group $(3.0 \pm 0.14$ versus $4.26 \pm 0.26 \mathrm{kcal})$ reflecting higher water, lower fat $(22.2$ \pm 1.8 versus $33.8 \pm 2.5 \% ; P<0.001)$ and lower protein $(7.7 \pm$ 0.5 versus $12.5 \pm 0.8 \% ; P<0.001)$ contents of weight gain in the SGA group.
\end{abstract}

\section{Abbreviations}

SGA, small for gestational age

AGA, appropriate for gestational age

VLBW, very low birth weight

The infant who has suffered from intrauterine malnutrition early in the third trimester of pregnancy is potentially at risk for continued growth retardation $(1,12)$, as well as learning and behavioral problems $(2,13,28)$. These disorders appear to be more prominent among those children whose growth failure began before 26-34 weeks of gestation, in a pregnancy proceeding until near term $(11,16)$. These findings have encouraged the delivery of SGA infants well before term in an attempt to decrease perinatal mortality (41) and to avoid further undernutrition at a critical period of rapid growth rate (42). In order to devise proper feeding regimens for these high risk infants, the metabolic consequences of intrauterine growth retardation need to be understood.

The hypermetabolism of malnourished newborns has been described by a number of authors $(20,33,35)$. However, a quantitative evaluation of the energy metabolism and substrate utilization in SGA infants of VLBW kept on the same diet as AGA matched controls has not been previously documented. We have evaluated and compared the utilization and storage of energy and macronutrients as well as the quality of growth of preterm VLBW SGA and AGA infants.

\section{PATIENTS AND METHODS}

Fourteen studies were undertaken in 6 SGA VLBW $(<1300 \mathrm{~g}$ birth weight) infants. All were below the third percentile at birth for weight, length, and head circumference as determined from Usher's intrauterine growth charts (40). Gestational age was calculated from the mothers' last menstrual period and confirmed by clinical evaluation (10). In four, the growth retardation was due to maternal toxemia or hypertension, and no cause was determined in the remaining two infants. No malformations or intrauterine infections were documented. Three studies were conducted for three of the infants, and in two infants, two studies were performed, at intervals of 1 or 2 weeks. For comparison, 22 studies in 13 AGA VLBW infants of similar birth weight and postnatal age are presented. The clinical characteristics of these two groups of VLBW preterm infants, cared for under the same thermoneutral conditions (19), are shown in Table 1.

Patients selected for this series of studies have met the following criteria: 1) birth weight is less than $1.3 \mathrm{~kg} ; 2$ ) they were either appropriate for gestational age (AGA group) or small for gestational age (SGA group) as assessed from mother's last menstrual period and clinical criteria $(10,40,41) ; 3)$ they were free from congenital anomalies and intrauterine infections; 4) they were 
Table 1. Growth and clinical parameters of SGA and AGA premature infants subject to the nutrional balance and energy metabolism studies*

\begin{tabular}{lcc} 
& SGA & AGA \\
\hline Number of studies & 14 & 22 \\
Number of infants & 6 & 13 \\
Birthweight (g) & $1120 \pm 30$ & $1155 \pm 40$ \\
Gestational age (wk) & $33.1 \pm 0.3$ & $29.3 \pm 0.4 \dagger$ \\
Age at study (days) & $26 \pm 3$ & $21 \pm 2$ \\
Weight at study (g) & $1550 \pm 50$ & $1270 \pm 60 \dagger$ \\
Weight gain (g/kg·day) & $19.4 \pm 0.9$ & $16.8 \pm 1$ \\
Length gain (cm/wk) & $1.25 \pm 0.14$ & $1.02 \pm 0.1$ \\
Head circumference gain (cm/wk) & $1.16 \pm 0.09$ & $0.94 \pm 0.08$ \\
\hline
\end{tabular}

${ }^{*}$ Results are expressed as mean $\pm \mathrm{SE}$.

$\dagger P<0.001$.

able to tolerate oral feedings within the 1st week of life; 5) they did not require the respiratory support of a ventilator beyond the 1st postnatal week; 6 ) they did not receive drugs which influence metabolic rate (e.g. theophylline, $\beta$-adrenergic stimulants, etc.); 7) they did not have clinical problems which might have adverse effects on oxygen consumption and carbon dioxide production such as metabolic or respiratory acidosis or alkalosis.

Each study was comprised of the following measurements: 1) nutritional balance on 3 consecutive days; 2) continuous open circuit indirect calorimetry with simultaneous measurement of urinary nitrogen excretion on the 2 nd day of the balance; 3 ) anthropometry. The technology was described in detail in our previous publications $(6,18,30,31,39)$. Informed parental consent was obtained.

Nutritional balance. The nutritional balance comprised measurements over 3 days of intake (formula: SMA 20/24) and losses (urine and stool) of macronutrients, as previously described (31). Infants were fed according to the standard practice in our unit. The volume of formula was increased as tolerated. At the age of 2 weeks, the SMA $20 \mathrm{kcal} /$ ounce was changed to SMA $24 \mathrm{kcal} /$ ounce in order to provide a caloric intake above $140 \mathrm{kcal} / \mathrm{kg}$. day. Macronutrient intake was determined from the volume of feeds retained and the manufacturer's stated content of substrates in the formula. The caloric values of $9.25 \mathrm{kcal} / \mathrm{g}$ of fat, 3.95 $\mathrm{kcal} / \mathrm{g}$ of carbohydrate, and $5.65 \mathrm{kcal} / \mathrm{g}$ of protein (32) were used in the calculations of the energy balance. Urine and stool were collected separately and their macronutrient content was determined as previously reported (31). The value for urinary nitrogen output was used for calculations (amount of nitrogen $\times 6.25$ ) of the amount of protein catabolized, or more precisely, the amount of amino acids deaminated and their carbon skeleton subjected to end oxidation or transfer to other macronutrient pools, e.g. gluconeogenesis from amino acids or lipogenesis from glucose, etc. Metabolizable energy and substrate intakes were determined by subtracting the energy losses in the urine and stool from the intake.

Indirect calorimetry. Energy metabolism was measured by continuous computerized open circuit indirect calorimetry over a mean period of $6 \mathrm{~h}$ as previously described $(6,30,31)$. Oxygen consumption ( $\dot{\mathrm{VO}}_{2}$ in $\left.\mathrm{ml} / \mathrm{kg} \cdot \mathrm{mi}, \mathrm{STPD}\right)$, carbon dioxide production $\dot{\mathrm{V}} \mathrm{CO}_{2}$ in $\mathrm{ml} / \mathrm{kg} \cdot \mathrm{min}$, STPD), respiratory quotient $(R=$ $\dot{\mathrm{V}} \mathrm{CO}_{2} / \dot{\mathrm{VO}}_{2}$ ) were determined using a paramagnetic $\mathrm{O}_{2}$ analyzer (Taylor-Servomex OA 184, Crowborough, England) and an infrared $\mathrm{CO}_{2}$ analyzer (Beckman LB2, Palo Alto, CA). Simultaneous measurement of urinary nitrogen excretion rates enabled determination of nitrogen free $\dot{\mathrm{VO}}_{2}$, nitrogen free $R$. The metabolic rate (kcal/ $\mathrm{kg}$.day) and differential oxidation of carbohydrate and fat participating in total caloric production, were calculated from the specific nitrogen free respiratory quotient and oxygen consumption $(18,24)$. The infant was studied in an incubator within the thermoneutral range (10) and environmental, core, and skin (at six different sites) temperatures continuously measured, enabling calculation of mean skin temperature
$(18,39)$ and monitoring of constancy of environmental conditions. From changes in core and mean skin temperatures, heat storage/loss were calculated over the time of the study, assuming a specific heat of body mass of $0.84 \mathrm{kcal} / \mathrm{kg} \cdot{ }^{\circ} \mathrm{C}(18,39)$. Activity was continuously monitored by an experienced observer and scored on the Brück scale (4) enabling differentiation of metabolic rate measured under resting conditions, from the metabolic rate measured under graded levels of activity. Resting metabolic rates were determined for periods of 10 to 30 min preprandially (within $1 \mathrm{~h}$ prior to a feed), with the infant in a resting state (i.e. Brück scale of $-3,-4$ ) for at least 10 min prior to the measurements. The resting metabolic rate was obtained in nine studies in the SGA group and 14 studies in the AGA group.

Anthropometry. The growth pattern was determined from increments in weight $(\mathrm{g} / \mathrm{kg} \cdot$ day), length $(\mathrm{cm} /$ week), head circumference $(\mathrm{cm} /$ week). The baby's weight was measured daily using an Air Shields balance (Narco Heath, Hatboro, PA). In order to minimize errors, weight gain was obtained by averaging the daily measurements over the week bracketing the balance study. Length was obtained on a measuring board; occipitofrontal head circumference was measured with a tape weekly.

Statistical analysis. For statistical evaluation of difference between means, the two-tailed Student's $t$ test was used.

\section{RESULTS}

The routine feeding schedule provided SGA and AGA infants with similar mean \pm SE volumes of formula (185 \pm 2 versus 180 $\pm 3 \mathrm{ml} / \mathrm{kg} \cdot$ day), and as shown in Table 2, comparable energy and substrate intakes. Energy losses in excreta were significantly greater $(P<0.001)$ in the SGA infants, due to a significantly poorer absorption $(\%)$ of fat $(68.7 \pm 3.2$ versus $79.7 \pm 1.7 ; P<$ $0.005)$ and protein $(69.1 \pm 3.2$ versus $83.4 \pm 1.5 ; P<0.001)$. Consequent to the SGA infants' relative malabsorption, their metabolizable protein intake was significantly lower $(P<0.001)$. However, the metabolizable intakes of energy, fat, and carbohydrate remained similar in both groups, as the SGA infants had received a slightly higher gross intake.

Energy utilization and storage. SGA infants presented a significantly higher $(P<0.001)$ mean metabolic rate $(67.4 \pm 1.3$ versus $62.6 \pm 0.9 \mathrm{kcal} / \mathrm{kg}$. day) (Table 3 ). Under resting condi-

Table 2. Metabolizable energy and macronutrient intakes and partition of losses in excretion*

\begin{tabular}{|c|c|c|c|}
\hline & SGA & AGA & $P$ \\
\hline \multicolumn{4}{|l|}{ Intake } \\
\hline Energy (kcal/kg·day) & $155.8 \pm 2.2$ & $148.6 \pm 3.9$ & NS \\
\hline \multicolumn{4}{|c|}{ Macronutrients (g/kg. day) } \\
\hline Fat & $8.0 \pm 0.1$ & $7.5 \pm 0.2$ & NS \\
\hline Carbohydrate & $16.0 \pm 0.2$ & $15.2 \pm 0.4$ & NS \\
\hline Protein $\dagger$ & $3.3 \pm 0.1$ & $3.2 \pm 0.1$ & NS \\
\hline \multicolumn{4}{|l|}{ Losses } \\
\hline Energy (kcal/kg·day) & $29.9 \pm 2.8$ & $18.2 \pm 1.5$ & $<0.001$ \\
\hline \multicolumn{4}{|c|}{ Macronutrients (g/kg. day) } \\
\hline \multicolumn{4}{|l|}{ Stool } \\
\hline Fat & $2.5 \pm 0.3$ & $1.5 \pm 0.1$ & $<0.005$ \\
\hline Carbohydrate & $0.05 \pm 0.01$ & $0.05 \pm 0.02$ & NS \\
\hline Protein $\dagger$ & $1.1 \pm 0.1$ & $0.55 \pm 0.05$ & $<0.001$ \\
\hline \multicolumn{4}{|l|}{ Urine } \\
\hline Carbohydrate & $0.10 \pm 0.01$ & $0.10 \pm 0.01$ & NS \\
\hline Protein $\dagger$ & $0.73 \pm 0.04$ & $0.73 \pm 0.03$ & NS \\
\hline \multicolumn{4}{|l|}{ Metabolizable intake } \\
\hline Energy (kcal/kd·day) & $125.9 \pm 2.5$ & $130.4 \pm 3.5$ & NS \\
\hline \multicolumn{4}{|l|}{ Macronutrient (g/kg. day) } \\
\hline Fat & $5.5 \pm 0.2$ & $6.0 \pm 0.2$ & NS \\
\hline Carbohydrate & $15.85 \pm 0.2$ & $15.05 \pm 0.2$ & NS \\
\hline Protein $\dagger$ & $2.2 \pm 0.1$ & $2.65 \pm 0.1$ & $<0.005$ \\
\hline
\end{tabular}

${ }^{*}$ Results are expressed as mean $\pm \mathrm{SE}$; NS, not significant. $\dagger$ Protein $=$ nitrogen $\times 6.25$. 
tions, the "basal" energy expenditure of these VLBW infants, measured as the resting preprandial metabolic rate (31), was also higher $(P<0.05)$ in the SGA infants. Thus, an increased energy cost of activity could not explain the relative hypermetabolism of the SGA infants. This further was documented (Fig. 1) by the partition of time spent by both groups at defined levels of activity. The SGA infants spent $42.8 \pm 5.0 \%$ of the time in quiet sleep (Brück scale, -4, -3), compared with $29.4 \pm 6.5 \%$ for AGA infants although these differences were not statistically significant. Furthermore, comparable values for heat storage (1.2 \pm 0.2 versus $0.9 \pm 0.01 \mathrm{kcal} / \mathrm{kg}$. day) could not account for the 4.8 $\mathrm{kcal} / \mathrm{kg}$. day larger total energy expenditure of SGA infants.

Of the metabolizable intakes of $125.9 \pm 2.5$ and $130.4 \pm 3.5$ $\mathrm{kcal} / \mathrm{kg} \cdot$ day, the SGA and AGA infants expended $67.4 \pm 1.3$ and $62.6 \pm 0.9 \mathrm{kcal} / \mathrm{kg}$. day, respectively. The remaining energy $(58.5 \pm 3.6$ and $67.8 \pm 3.0 \mathrm{kcal} / \mathrm{kg}$. day $)$, stored in components of new tissue (Table 4), was higher $(P<0.05)$ in the AGA infants.

Macronutrient utilization and storage. The nitrogen free $R$ of 0.949 in the SGA infants represented the differential participa-

Table 3. Calorimetric measurements*

\begin{tabular}{lccc}
\hline & SGA & AGA & $P$ \\
\hline$\dot{\mathrm{VO}}_{2}(\mathrm{ml} / \mathrm{kg} \cdot \mathrm{min})$ & $9.37 \pm 0.2$ & $8.66 \pm 0.11$ & $<0.005$ \\
Respiratory quotient $(R)$ & $0.940 \pm 0.01$ & $0.960 \pm 0.009$ & $\mathrm{NS}$ \\
Urinary nitrogen $(\mathrm{mg} / \mathrm{kg} \cdot$ day) & $116 \pm 8$ & $118 \pm 6$ & $\mathrm{NS}$ \\
Nitrogen free $\mathrm{V}_{2}(\mathrm{ml} / \mathrm{kg} \cdot \mathrm{min})$ & $8.88 \pm 0.2$ & $8.16 \pm 0.1$ & $<0.005$ \\
Nitrogen free $R$ & $0.949 \pm 0.01$ & $0.970 \pm 0.009$ & $\mathrm{NS}$ \\
Metabolic rate $(\mathrm{MR} ; \mathrm{kcal} / \mathrm{kg} \cdot$ & $67.4 \pm 1.3$ & $62.6 \pm 0.9$ & $<0.005$ \\
day) & & & \\
Resting preprandial MR $(\mathrm{kcal} /$ & $57.6 \pm 1.0$ & $54.2 \pm 1.3$ & $<0.05$ \\
$\mathrm{~kg} \cdot$ day) & & & \\
\hline
\end{tabular}

${ }^{*}$ Results are expressed as mean \pm SE; NS, not significant.

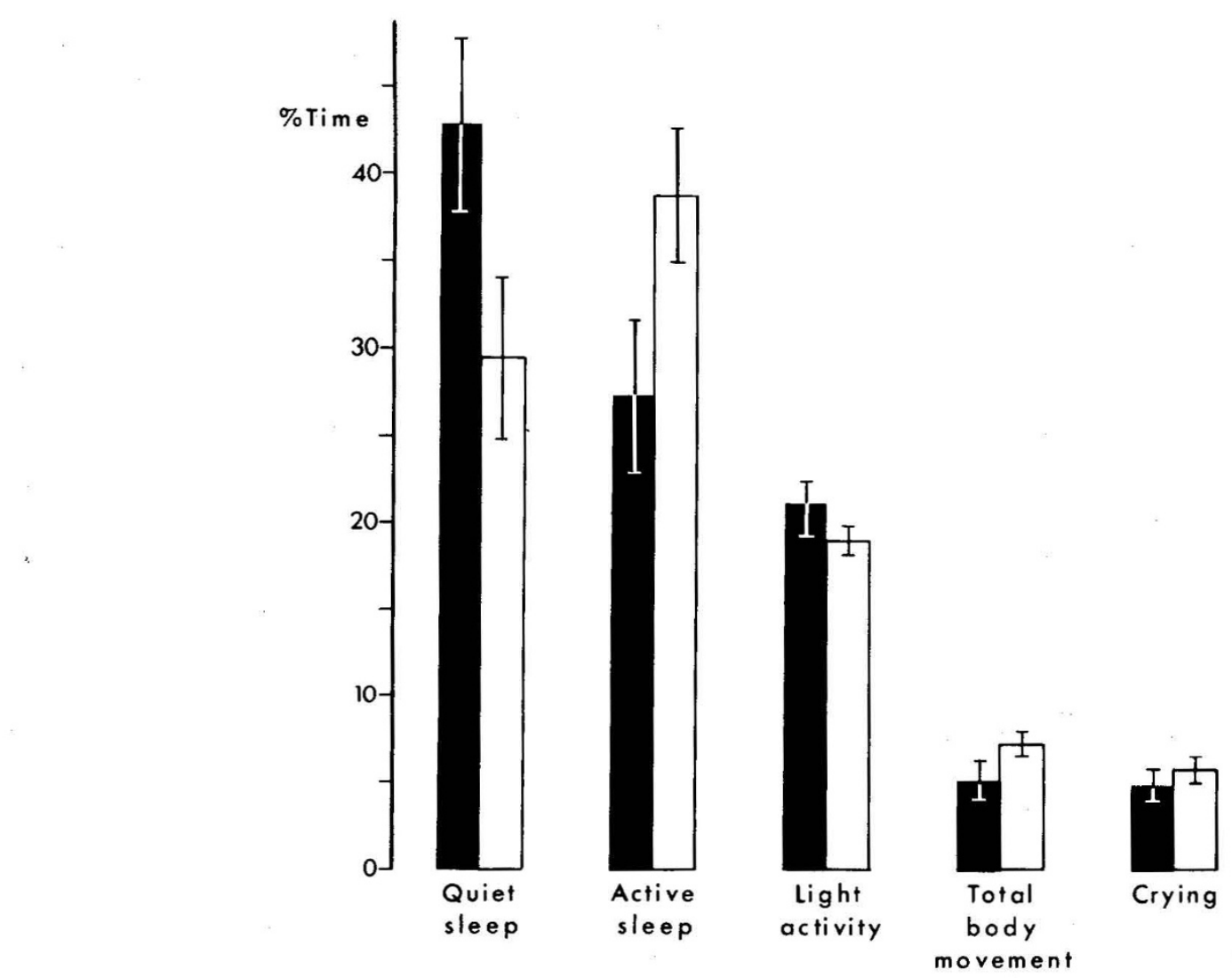

tion in nonprotein heat production of $83 \%$ from carbohydrate and $17 \%$ from fat oxidation (24), whereas in the AGA infants (nitrogen free $R=0.970$ ) $90 \%$ was derived from carbohydrate and $10 \%$ from fat oxidation (Table 4). In the SGA and AGA infants the mean metabolic rates were derived from the oxidation of $1.2 \pm 0.3$ and $0.6 \pm 0.3 \mathrm{~g} / \mathrm{kg} \cdot$ day of fat, $13.2 \pm 0.6$ and 13.3 $\pm 0.5 \mathrm{~g} / \mathrm{kg}$. day of carbohydrate, $0.73 \pm 0.04$ and $0.73 \pm 0.03 \mathrm{~g} /$ $\mathrm{kg}$. day of protein. The hypermetabolism of the SGA infants was associated with the larger fat oxidation.

The deposition of macronutrients was determined by subtraction of the amounts oxidized from the metabolizable intakes. The lower energy storage of the SGA infants was due to a significantly lower deposition of fat $(4.3 \pm 0.4$ versus $5.4 \pm 0.3$ $\mathrm{g} / \mathrm{kg} \cdot$ day; $P<0.05)$ and protein $(1.57 \pm 0.12$ versus $1.92 \pm 0.08$ $\mathrm{g} / \mathrm{kg} \cdot$ day; $P<0.05)$.

Composition of weight gain. Despite lower energy and nutrient accretion, the SGA infants gained weight, length, and head circumference at higher rates than the AGA group (Table 1). For each gram of weight gain, the SGA infants stored $3.0 \pm 0.1 \mathrm{kcal}$ and the AGA infants $4.2 \pm 0.2 \mathrm{kcal}(P<0.001)$. The composition of weight gain was determined as the relative proportion of fat and protein accretion to total weight gain. As shown in Figure 2, the fat and protein contents of weight gain were significantly lower $(P<0.001)$ in the SGA infants. Fat deposition accounted for $22.2 \pm 1.8$ versus $33.8 \pm 2.5 \%$ of weight gain, and protein for $7.7 \pm 0.5$ versus $12.5 \pm 0.8 \%$ in the sGA and AGA infants, respectively.

\section{DISCUSSION}

The studies performed in SGA and AGA VLBW infants demonstrate different metabolic responses to the diet in nutrient absorption, energy metabolism, growth, and composition of newly laid down tissue. These differences could be related to the

Fig. 1. Percentage study time spent by SGA (black bars) and AGA (white bars) VLBW infants at defined activity levels. For clarity, scores on the 10 point Brück scale $(-4$ to +5$)(4)$ are reported, grouped as follows: $(-4,-3)$ quiet sleep, $(-2)$ active sleep, $(-1,0,+1)$ light activity with eyes open or closed, $(+2,+3)$ total body movements, $(+4,+5)$ crying. Results are graphed as mean \pm SE. Differences between means were not statistically significant. 
Table 4. Energy and macronutrient storage*

\begin{tabular}{|c|c|c|c|}
\hline & SGA & AGA & $P$ \\
\hline \multicolumn{4}{|l|}{ Metabolizable intake } \\
\hline Energy (kcal/kg·day) & $125.9 \pm 2.5$ & $130.4 \pm 3.5$ & NS \\
\hline \multicolumn{4}{|c|}{ Macronutrients $(\mathrm{g} / \mathrm{kg} \cdot$ day $)$} \\
\hline Fat & $5.5 \pm 0.2$ & $6.0 \pm 0.2$ & NS \\
\hline Carbohydrate & $15.85 \pm 0.2$ & $15.05 \pm 0.4$ & NS \\
\hline Protein $\dagger$ & $2.2 \pm 0.1$ & $2.65 \pm 0.1$ & $<0.005$ \\
\hline \multicolumn{4}{|l|}{ Oxidation } \\
\hline Energy $(\mathrm{kcal} / \mathrm{kg} \cdot$ day $)$ & $67.4 \pm 1.3$ & $62.6 \pm 0.9$ & $<0.005$ \\
\hline \multicolumn{4}{|c|}{ Macronutrients $(\mathrm{g} / \mathrm{kg} \cdot$ day $)$} \\
\hline Fat & $1.2 \pm 0.3$ & $0.6 \pm 0.3$ & NS \\
\hline Carbohydrate & $13.2 \pm 0.6$ & $13.3 \pm 0.5$ & NS \\
\hline Protein $\dagger$ & $0.73 \pm 0.04$ & $0.73 \pm 0.03$ & NS \\
\hline \multicolumn{4}{|l|}{ Deposition } \\
\hline Energy (kcal/kg·day) & $58.5 \pm 3.6$ & $67.8 \pm 3.0$ & $=0.05$ \\
\hline \multicolumn{4}{|c|}{ Macronutrients $(\mathrm{g} / \mathrm{kg} \cdot$ day) } \\
\hline Fat & $4.3 \pm 0.4$ & $5.4 \pm 0.3$ & $<0.05$ \\
\hline Carbohyd & $2.6 \pm 0.4$ & $1.8 \pm 0.4$ & NS \\
\hline Protein $\dagger$ & $1.57 \pm 0.12$ & $1.92 \pm 0.08$ & $<0.05$ \\
\hline
\end{tabular}

${ }^{*}$ Results are expressed as mean $\pm \mathrm{SE}$; NS, not significant.

$\dagger$ Protein $=$ nitrogen $\times 6.25$.

FETUS

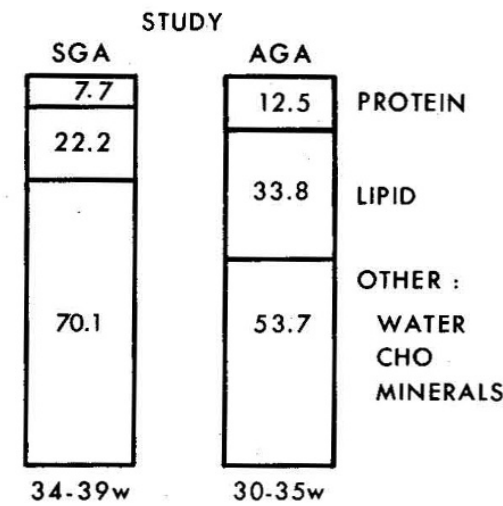

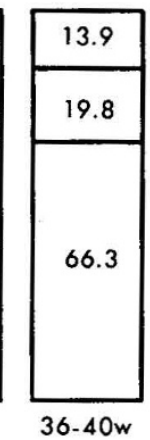

Fig. 2. Comparison of the percentage composition of weight gain
between the mean values for SGA (from 34 to 39 weeks of gestation) and AGA (from 30 to 35 weeks) VLBW infants, and reported values for the fetus (from 28 to 32 weeks and 36 to 40 weeks) (44).

maturation process of metabolically active cell mass, since the SGA infants were 3 weeks more mature, of similar birthweight and postnatal age at study, and had been cared for under the same conditions. The repeated studies undertaken in several infants at intervals of 1-2 weeks have not introduced a bias in the results since intraindividual and interindividual variances were similar.

Little is known concerning the absorption processes in SGA VLBW infants. We found that SGA infants had a significantly $(P<0.001)$ higher energy loss in excreta because of a $11-14 \%$ lower absorption of both protein and fat. However, the metabolizable intakes of energy and macronutrients were similar in both groups as the SGA infants had received slightly higher intakes (Table 2). Similar differences in protein absorption have been reported in a small number of comparative studies on protein turnover in SGA and AGA VLBW infants (29). Although differences did not reach statistical significance, lower protein digestibility was found in SGA compared to AGA infants consistent with our findings of protein malabsorption in the preterm SGA infant. Others (27) have shown a significant impairment of Dxylose and D-glucose absorption in growth-retarded infants over the first few weeks of postnatal life. In animals, differences in pancreatic development (9) and size of small intestine (22) have been found between growth-retarded and normal newborn rats. Fetal malnutrition caused in these animals a selective decrease in some brush-border enzymes. In postnatal malnutrition, di- minished enzymatic activity of lipase and trypsin were described (17). These animal studies offer the pathophysiological basis for our findings of relative fat and protein malabsorption in SGA VLBW infants. We found similar absorption (Table 2) of carbohydrate in both groups. However, with hydrogen breath tests (25) and stable isotope studies (26), it has been shown that larger proportions of lactose escape absorption in the small intestine before being fermented by colonic bacteria. In mammals (37), fecal bacteria have been found to ferment carbohydrate into rapidly absorbed volatile fatty acids. Similarly, in human adults (3), the recovery of carbon atoms and calories derived from the colonic fermentation of carbohydrate has been described. This process could explain the low recovery of carbohydrate excretion $(0.05 \mathrm{~g} / \mathrm{kg}$. day) and the substantial carbohydrate depositions (2.6 and $1.8 \mathrm{~g} / \mathrm{kg}$-day). In both SGA and AGA infants, part of this retained carbohydrate may first be converted into volatile fatty acids in the colon and after absorption and chain elongation in the liver appear in the fat pool. This interconversion of glucose carbon to fatty acid carbon is an energy-consuming process (18, 43) which might have contributed to the differences in global energy expenditure of SGA and AGA infants.

Age, weight, relative organ size, growth rate, caloric intake, activity, and thermal environment are the major determinants of metabolic rate in infants $(6,18,31)$. We have found in preterm SGA infants a relatively higher metabolic rate (by $4.8 \mathrm{kcal} / \mathrm{kg}$. day), than in AGA VLBW infants. The hypermetabolism of the SGA infants is unlikely due to an increase in the energy cost of activity, since the higher energy expenditure persisted under resting conditions (Table 3 ) and the time spent at different levels of physical activity was similar in the two groups (Fig. 1). Furthermore, we have previously shown (31) that the cost of activity is a small component $(6.8 \%)$ of the energy expenditure of VLBW infant.

The faster growth rate of the SGA infants (Table 1) could be a further source of hypermetabolism as energy is expended in the organization and deposition of new tissue. When applying the figure for energy cost of growth of VLBW infants $(0.67 \mathrm{kcal} /$ $\mathrm{g}$ weight gain), previously reported by us (6), to the $2.6 \mathrm{~g} / \mathrm{kg}$. day higher weight gain of the SGA infants, only $1.74 \mathrm{kcal} / \mathrm{kg}$. or $36 \%$ of the SGA infants' hypermetabolism $(1.74 / 4.8 \times 100)$ could be accounted for. Furthermore, the deposition of protein and fat being significantly smaller in the SGA infant (Table 4), the energy cost of growth is an unlikely source of this hypermetabolism.

Sinclair (36) speculated that the metabolic rate of the brain, which is characteristically large in relation to body weight, might account for the hypermetabolism of the SGA infant. Others (23) similarly hypothesize that the relatively large size of the brain may be of importance in causing the relative hypermetabolism in undergrown infants with severe heart disease. From postmortem analysis of organ size in growth-retarded and normal infants (14), it is apparent that the single major organ size difference is the heavier brain weight in SGA infants. Assuming that the increased metabolic rate and $\dot{\mathrm{VO}}_{2}$ found in our SGA infants would be due solely to their larger brains, we calculated cerebral energy expenditure or oxygen consumption. Using indices proposed by Cooke et al. (7), brain weight was estimated in both groups (SGA, $227 \pm 13$; AGA, $202 \pm 9 \mathrm{~g}$ ) from mean head circumference (SGA, $29.8 \pm 0.4 ;$ AGA, $27.7 \pm 0.4 \mathrm{~cm}$ ). From the differences between both groups in brain weight $(19.5 \mathrm{~g} / \mathrm{kg}$ body weight $)$, metabolic rate $\left(4.8 \mathrm{kcal} / \mathrm{kg}\right.$-day) and $\dot{\mathrm{VO}}_{2}(0.71$ $\mathrm{ml} / \mathrm{kg} \cdot$ day), the SGA infants cerebral metabolic rate and oxygen uptake were estimated as $4.8 / 19.5=0.24 \mathrm{kcal} / \mathrm{g}$ brain tissue/ day and $(0.71 \times 100) / 19.5=3.6 \mathrm{ml} \mathrm{O}_{2} / 100 \mathrm{~g}$ brain tissue $/ \mathrm{min}$. These values are comparable to those found in children using, cerebral A-V O $\mathrm{O}_{2}$ differences (34), measurements of brain heat production (38), and nitrous oxide measurements of cerebral blood flow (21). These data show that brain metabolism accounts for $50 \%$ or more of the energy expenditure in both the AGA and SGA VLBW infants and suggest that the brain is one of the most 
important sites of energy utilization in these infants. Moreover our results imply that the hypermetabolism of the SGA infant is probably due to two factors: higher rate of growth and larger brain size.

The SGA infants exhibited a "catch-up" growth as they were gaining weight, length, and head circumference at faster rates than the AGA group (Table 1). Davies (8) suggested that this characteristic battern of earlv growth of small-for-dates hahies ic
20. Hill JR, Robinson DC 1968 Oxygen consumption in normally grown, smallfor-dates and large-for-dates newborn infants. J Physiol (Lond) 199:685

21. Kennedy C, Sokoloff L 1957 An adaptation of the nitrous oxide method to the study of the cerebral blood flow and cerebral metabolic rate in childhood. J Clin Invest 36:1130

22. Lebenthal E, Nitzan M, Lee PC, Chrzanowski BL, Krasher J 1981 Effect of intrauterine growth retardation on the activities of fetal intestinal enzymes in rats. Biol Neonate 39:14

23. Lees MH, Briston JD, Griswold HE, Olmsted RW 1965 Relative hyperme-

\section{International coverage of the most}

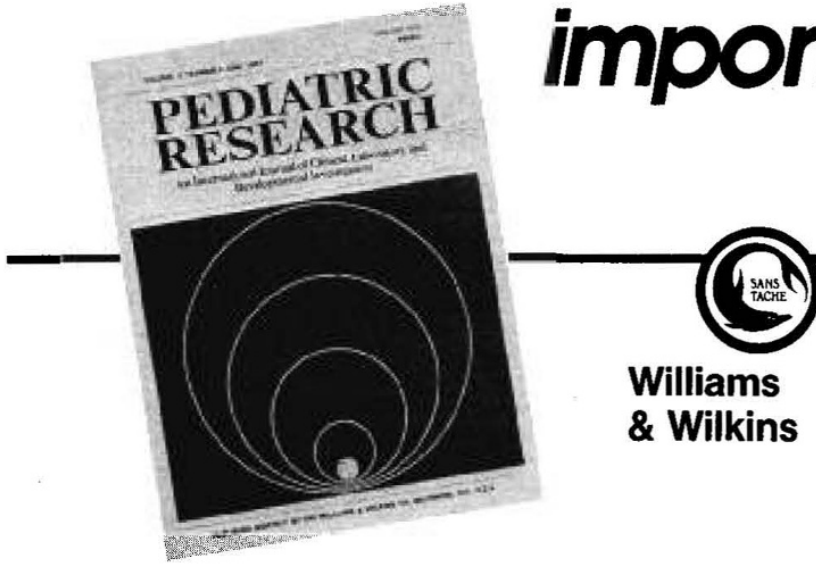

PEDIATRIC RESEARCH

An International Journal of Clinical, Laboratory, and Developmental Investigation

Editor-in-Chief: Delbert A. Fisher, MD

A very month, Pediatric Research puts you in

E touch with leading authorities in pediatric pulmonology, endocrinology and metabolism, gastroenterology, and nutrition. You'll read about significant new clinical and laboratory results, as selected and reported by an international array of distinguished contributors and editors.

Letters to the editor on topics of current interest, abstracts of major society meetings worldwide, and occasional supplements on specific issues in pediatric health are also part of the package, but the hallmark of Pediatric Research is research, and lots of it. Each issue contains some 15 original articles4 to 6 pages each-on late-breaking investigations into the most difficult problems of childhood disease. Cystic fibrosis, hypopituitarism, sudden infant death syndrome, protein intolerance, metabolic disorders, and sickle cell anemia are just a few of the subjects covered in recent issues. As advances are made in the understanding and management of these and other baffling childhood disorders, Pediatric Research will continue to be there with timely, accurate, and useful reports from leaders in the field. Monthly

Personal: $\$ 75 / \mathrm{yr}$ Institutions: $\$ 100 / \mathrm{yr}$

In-training: $\$ 55 / \mathrm{yr} \quad$ (add $\$ 12.00$ outside the US)

FOR FASTEST SERVICE, call 1-800-638-6243 FREE from anywhere in the US except $\mathrm{AK}$ and $\mathrm{HI}$. MD residents, call $528-4105$ collect.

\section{PEDIATRIC RESEARCH \\ An International Journal of Clinical, Laboratory, and Developmental Investigation}

\section{Research you can't afford to miss... and an offer you can't afford to pass up}

Avoid planned rate increases and ensure uninterrupted service by subscribing to PEDIATRIC

RESEARCH for up to 3 years at current rates.

$\square$ New subscription $\quad \square$ Renewal
$\square$ 3yrs $\square$ 2 yrs $\square$ 1 yr
$\square$ Personal: $\$ 75 /$ yr $\quad \square$ Institutions: $\$ 100 /$ yr
$\square$ In-training: $\$ 55 /$ yr
(add \$12.00 outside the US)
$\square$ check enclosed $\square$ bill me
$\square$ VISA $\square$ MasterCard $\square$ American Express

card \# exp.

signature/P.0. \#

MD residents, please add $5 \%$ sales tax. Subscriptions outside the US and Canada must be prepaid, in US dollars only. Residents, fellows, interns, and students: when applying for the in-training rate, which is limited to three years, please include institution name and training status. Rates valid through October 31, 1984.

Please allow 8 weeks for delivery of your first issue. Surface mail delivery to countries outside the US may take up to 16 weeks. Airmail rates available upon request.

\section{Name}

Address

City/State/Zip

\section{Williams \& Wilkins}

P.O. Box 1496

Baltimore, Maryland 21203

266 Fulham Road

I nndnn SW10 9F

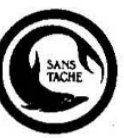

